\title{
PENGARUH RETURN SAHAM, ASSETS TURNOVER, LEVERAGE, DAN PRICE TO BOOK VALUE TERHADAP DEVIASI ACTUAL GROWTH RATE DARI SUSTAINABLE GROWTH RATE
}

\author{
Hesty Erviani Zulaecha ${ }^{(1)}$ \\ hestyerviani2005@gmail.com \\ Universitas Muhammadiyah Tangerang \\ Dewi Rachmania ${ }^{(2)}$ \\ dewi.rachmania78@gmail.com \\ Universitas Muhammadiyah Tangerang \\ Mohamad Zulman Hakim ${ }^{(3)}$ \\ zulman.hakim@umt.ac.id \\ Universitas Muhammadiyah Tangerang \\ Sri Utami ${ }^{(4)}$ \\ sriutami.0596@gmail.com \\ Universitas Muhammadiyah Tangerang
}

\begin{abstract}
ABSTRAK
The purpose of this study was to determine the effect of stock returns, asset turnover, leverage, and price to book value to the deviation of the actual growth rate of sustainable growth rates in manufacturing companies on the Indonesia Stock Exchange (IDX). The time period of the study is 4 years, namely the period 2015-2018.

The population of this study includes all manufacturing companies listed on the Indonesia Stock Exchange (IDX) for the 2015-2018 period. The sampling technique uses purposive sampling technique. Based on the established criteria obtained by 17 companies. The type of data used is secondary data obtained from the Indonesia Stock Exchange website. The analytical method used is panel data regression analysis.

The results showed that stock returns, asset turnover, and leverage significantly positive effect on the deviation of the actual growth rate of the sustainable growth rate, price to book value had a significant negative effect on the deviation of the actual growth rate of the sustainable growth rate, and stock returns, asset turnover, leverage, and price to book value together affect the actual growth rate deviation from the sustainable growth rate.
\end{abstract}

Keywords : sustainable growth rate, return saham, assets turnover, leverage, price to book value 


\section{PENDAHULUAN}

Belakangan ini perusahaanperusahaan menghadapi era globalisasi yang ditandai dengan pesatnya perkembangan perekonomian Indonesia saat ini, perusahaan dituntut untuk dapat lebih meningkatkan kinerjanya agar dapat bertahan di dalam menghadapi perkembangan perekonomian yang selalu berubah dengan cepat dan dinamis. Kebanyakan manajemen berpikir bahwa pertumbuhan perusahaan harus tinggi. Alasannya sederhana, karena semakin tinggi tingkat pertumbuhan perusahaan maka pendapatan dan laba perusahaan akan bertambah. Namun, dari aspek finansial perusahaan, pertumbuhan tidak selalu merupakan hal yang positif. Tingkat pertumbuhan yang meningkat terlalu tinggi dan cepat akan menyebabkan kebutuhan modal kerja (working capital) menjadi semakin tinggi, dan apabila manajemen tidak menyadari, dan tidak mengevaluasi pertumbuhan perusahaan, maka hal ini dapat berujung pada kesulitan keuangan suatu perusahaan. Perusahaan yang mempunyai rencana ekspansi membutuhkan tambahan dana dari pihak eksternal baik melalui kreditor maupun penjualan saham di pasar modal.

Hal ini menjadi pertimbangan oleh bank selaku kreditor dan investor apakah perusahaan memiliki prospek pertumbuhan seperti laba dan aset. Bagi kreditor dengan pemberian pinjaman kepada perusahaan yang memiliki prospek keuntungan akan memberikan bunga diluar pinjaman pokok, sedangkan bagi investor modal yang ditanamkan kepada perusahaan dapat memberikan return yang maksimal. Maka perusahaan yang memiliki prospek pertumbuhan pada kinerja bisnis akan sangat diminati.Sampai saat ini, pertimbangan pertumbuhan laba sering dilakukan untuk mengukur kinerja bisnis. Namun disamping laba, ada alat pengukuran yang lebih bermanfaat dan sering digunakan sebagai alat pengukuran kemampuan keuangan pada sebuah organisasi yaitu

Sustainable Growth Rate (SGR). Pertumbuhan penjualan disertai laba dapat meningkatkan aset lalu kenaikan dalam aset tanpa pengeluaran modal merupakan syarat pertumbuhan, tiap aset yang naik harus didanai dengan tambahan kewajiban atau dari laba ditahan sehingga bila kebijakan keuangan tidak diubah maka tingkat pertumbuhan modal pemegang saham akan membatasi pertumbuhan penjualan. Hal tersebut mengindikasi bahwa terdapat ketidaksinkronan khususnya antara pertumbuhan penjualan (elemen operasi) dengan struktur modal (elemen keuangan) yang memiliki arah berbeda dalam menilai suatu kebijakan dalam perusahaan (Saputro \& Purwanto, 2013). Sustainable growth rate merupakan konsep yang didasarkan pada teori keagenan (agency theory) dan teori sinyal (signalling theory) yang digunakakan untuk melihat kemajuan suatu perusahaan, apakah keputusan pihak pengelola perusahaan dapat memberikan return atas investasi yang diberikan pemilik perusahaan atau penyetor dana dan menjadi suatu alat pemersatu persepsi tentang kondisi perusahaan antara pihak manajemen perusahaan dan investor serta sebagai sinyal kepada para investornya, sehingga para pihak eksternal tersebut terutama pihak investor, tepat dalam melakukan transaksi di pasar saham dan bisa menjadi suatu hubungan yang saling menguntungkan antar kedua belah pihak.

Sustainable growth rate ialah tingkat maksimum dimana penjualan perusahaan bisa naik tanpa kehabisan sumber daya keuangan (Saputro \& Purwanto, 2013). Menurut Saputro \& Purwanto (2013) Sustainable Growth Rate (SGR) adalah metrik multifaset yang dapat dibagi menjadi komponen terpisah yang mencerminkan kebijakan retensi perusahaan (retention rate), kemampuan penahan biaya (net profit margin), efisiensi pemanfaatan aset (assets turnover), dan strategi pembiayaan (financial leverage), yang semuanya merupakan kunci penentu kinerja perusahaan. Alasan utama sustainable growth rate dinilai sangat bermanfaat karena dapat mengkombinasikan elemen operasi (profit margin dan efisiensi aset) dan elemen keuangan (struktur modal dan 
tingkat retensi) ke dalam satu ukuran yang komprehensif. Apabila sustainable growth rate hanya memiliki kelebihan dalam penentuan penggunaan biaya peningkatan aset yang tepat, pertanyaannya: mengapa konsep sustainable growth rate yang dipenuhi berbagai elemen dapat mengakomodasi berbagai kepentingan baik manajer maupun investor. Benarkah konsep itu didorong motivasi untuk mengambil keuntungan yang berkelanjutan di masa depan.

Hal tersebut mendorong pihak-pihak yang berkepentingan dalam perusahaan untuk mengetahui hubungan yang terjadi antara manfaat yang diterima dengan tingkat pertumbuhan penjualan pada perusahaan. Menurut Saputro \& Purwanto (2013) konsep sustainable growth rate bernilai karena menekan hubungan antara empat unsur penyusun sustainable growth rate dengan sustainable growth rate itu sendiri. Salah satu hal tersebut menandakan bahwa dengan membuat kenaikan pinjaman pada perubahan kebijakan keuangan tentu akan dapat menaikan sustainable growth rate. Namun hal tersebut juga akan mengurangi profitabilitas karena biaya bunga yang tinggi sehingga hubungan antara dua kompenen tersebut akan saling menekan. Dengan demikian jelas bila perusahaan tidak mau menerbitkan saham atau merubah profitabilitas, asset turnover, kebijakan keuangan atau kebijakan dividen, salah satu unsur sustainable growth rate maka hal tersebut membuat unsur sustainable growth rate yang lain juga dapat berubah akibat mendapat tekanan.

Dampak sustainable growth rate terhadap keuntungan investor dijelaskan pula oleh Saputro \& Purwanto (2013) yang menyatakan bahwa apabila perusahaan berusaha untuk mencapai target rasio modal terstruktur, kenaikan ekuitas akan memicu peningkatan proporsional dalam utang, perusahaan enggan untuk menerbitkan saham baru saat sustainable growth rate sama dengan persentase perubahan ekuitas buku. Dengan demikian terbukti ada hubungannya dengan return saham berikutnya karena peningkatan modal tersebut digunakan untuk membiayai pertumbuhan aset dan penjualan. Hal tersebut menandakan bahwa pada kebijakan keuangan mengenai perubahan pinjaman khususnya menunjukan arah yang berbeda pada kondisi keuangan mengenai tingkat pertumbuhan penjualan perusahaan yang sama.Pada penelitian yang dilakukan Saputro \& Purwanto (2013) menunjukan bahwa Return Saham berpengaruh negatif dan tidak signifikan terhadap Deviasi Actual Growth Ratedari Sustainable Growth Rate. Hal ini sejalan dengan penelitian yang dilakukan oleh Parmanto \& Murtini (2014) yang menyatakan bahwa Return Saham secara parsial tidak berpengaruh terhadap Deviasi Actual Growth Ratedari Sustainable Growth Rate.

Assets turnover adalah faktor lainnya yang sustainable growth rate. Total Assets Turnover (TATO) menggambarkan perputaran aktiva diukur dari volume penjualan. Jadi, semakin besar rasio ini, semakin baik yang berarti aktiva dapat lebih cepat berputar dan meraih laba dan menunjukkan semakin efisien penggunaan keseluruhan aktiva dalam menghasilkan penjualan. Dengan kata lain, jumlah aset yang sama dapat memperbesar volume penjualan apabila assets turn overnya ditingkatkan atau diperbesar (Wardiyah, 2017). Pada penelitian yang dilakukan Nasim \& Rizki Irnama (2017) menunjukan bahwa Total Assets Turnover (TATO) berpengaruh positif terhadap Sustainable Growth Rate. Hal ini berbeda dengan penelitian yang dilakukan oleh Parmanto \& Murtini (2014) yang menyatakan bahwa Total Assets Turnover (TATO) secara parsial berpengaruh terhadap deviasi antara actual dan sustainable growth rate.

Faktor yang mempengaruhi sustainable growth rate lainnya adalah debt to equity ratio (DER). Rasio ini nantinya akan memperbandingkan komposisi hutang perusahaan dengan modal yang dimiliki perusahaan. Kondisi pasar yang baik mencerminkan adanya pertumbuhan nilai perusahaan. Pada kondisi ini pula perusahaan akan 
menambah kegiatan operasional agar dapat manjaga pertumbuhan yang baik, maka perusahaan membutuhkan tambahan dana dari luar perusahaan sebagai tambahan modalnya. Penambahan dana ini bagi pelaku pasar dianggap wajar dan diharapkan pertumbuhan tersebut dapat melakukan ekspansi usahanya sehingga nantinya sustainable growth rate tercapai (Sari, 2014). Pada penelitian yang dilakukan Gunawan \& Leonnita (2015) menunjukan hasil bahwa debt to equity ratio (DER) berpengaruh positif terhadap Deviation Actual Growth Rate dari Sustainable Growth Rate. Hal ini berbeda dengan penelitian yang dilakukan oleh Putra (2015) yang menyatakan bahwa debt to equity ratio (DER) tidak berpengaruh signifikan terhadap deviasi actual growth rate dari sustainable growth rate (DAS).

Hal lain yang harus diperhatikan perusahaan untuk meningkatkan nilai jual perusahaan, dapat dilihat dari nilai pasar atau nilai sahamnya dengan mengukur price to book value (PBV). Perusahaan dengan kinerja yang baik akan memiliki nilai saham yang tinggi, begitu juga sebaliknya. Nilai saham yang tinggi mencerminkan investor mengganggapbaik kinerja yang dilakukan perusahaan. Dengan begitu akan mempermudah perusahaan dalam urusan pendanaan dan memperluas bisnisnya. Apabila keperluan pendanaan terpenuhi, kegiatan perusahaan tidak akan terganggu yang kemudian dapat berdampak pada pertumbuhan perusahaan.Pada penelitian yang dilakukan Putra (2015) menunjukan hasil bahwa price to book value (PBV) tidak berpengaruh signifikan terhadap deviasi actual growth rate dari sustainable growth rate (DAS). Hal ini berbeda dengan penelitian yang dilakukan oleh Saputro \& Purwanto (2013) yang menyatakan bahwa price to book ratio berpengaruh positif terhadap deviasi actual growth rate dari sustainable growth rate (DAS).

\section{TINJAUAN PUSTAKA DAN PERUMUSAN HIPOTESIS}

\section{Sustainable Growth Rate}

Saputro \& Purwanto (2013) menjelaskan bahwa Sustainable Growth Rate (SGR) merupakan tingkat maksimum dimana penjualan perusahaan dapat meningkat tanpa menghabiskan sumber daya keuangan. Dalam menentukan formulasi pengungkapan ketergantungan pertumbuhan penjualan pada sumber daya keuangan, diasumsikan bahwa Saputro \& Purwanto (2013) : (1) Perusahaan ingin tumbuh secepat kondisi pasar bila memungkinkan, (2) Manajemen tidak mampu atau tidak mau untuk menjual saham baru, (3) Perusahaan memiliki target struktur modal dan kebijakan dividen yang dipertahankan. Peningkatan penjualan membutuhkan aset baru yang didanai oleh sumber keuangan perusahaan baik dari kenaikan kewajiban dan laba ditahan dengan asumsi perusahaan tidak akan menjual saham.

Dengan asumsi bahwa bisnis terus berkembang baik ekuitas dan kewajiban akan meningkat secara proporsional tanpa mengubah struktur modal dan secara bersama-bersama pertumbuhan kewajiban dan ekuitas menentukan tingkat pertumbuhan aset. Lalu pada akhirnya sustainable growth rate akan dibatasi oleh ekuitas pemilik yang mengembang, sehingga sustainable growth rate merupakan laju dari pertumbuhan ekuitas.

\section{Actual Growth Rate}

Actual growth rate adalah presentase perubahan dari penjualan dalam satu periode ke periode berikutnya (Saputro dan Purwanto, 2013). Saputro \& Purwanto (2013) menyatakan bahwa rencana keuangan dari pertumbuhan berkelanjutan berarti pertumbuhan aktual pada penjualan (actual growth rate) harus diselaraskan dengan sumber daya baik pertumbuhan yang lebih cepat atau lambat yang dapat menimbulkan krisis baik keuangan maupun kelangsungan hidup perusahaan.

Deviasi actual growth rate dari sustainable growth rate merupakan selisih antara actual growth rate dan sustainable growth rate. Nilai Deviasi actual growth rate dari sustainable growth rate menunjukkan keidealan pertumbuhan 
perusahaan. Nilai deviasi ini akan digunakan manajemen dalam melakukan perubahan kebijakan operasi maupun keuangan.

\section{Return Saham}

Return adalah hasil (keuntungan atau kerugian) yang diperoleh dari suatu investasi saham. Return saham merupakan tujuan utama seorang investor dalam berinvestasi yaitu untuk mendapatkan keuntungan dari investasi tersebut (Hakim dan Abbas, 2019). Return saham bisa positif dan bisajuga negatif. Jika positif berarti mendapatkan keuntungan atau mendapatkan capital gain, sedangkan negatif berarti menderita kerugian atau capital loss (Hermuningsih, Rahmawati, \& Mujino, 2018). Tingkat keuntungan yang dinikmati oleh investor atas suatu investasi yang dilakukannya disebut return. Dan investor tentunya tidak akan melakukan investasi jika tanpa adanya ekspektasi akan return yang diperoleh di masa yang akan datang.

\section{Assets Turnover}

Assets turnover merupakan perbandingan antara penjualan dengan aktiva suatu perusahaan dimana rasio ini menggambarkan kecepatan perputarannya aktiva dalam sat periode tertentu. Perputaran total aset yang rendah berarti perusahaan memiliki kelebihan total aset, dimana total aset yang ada belum dimanfaatkan secara maksimal untuk menciptakan penjualan (Hery, 2016).

Total assets turnover ini penting bagi para kreditur dan pemilik perusahaan, tapi akan lebih penting lagi bagi manajemen perusahaan, karena hal ini akan menunjukkan efisien tidaknya penggunaan seluruh aktiva dalam perusahaan (Wardiyah, 2017).

\section{Leverage}

Leverage adalah penggunaan aset dan sumber dana (sources of funds) oleh perusahaan yang memiliki biaya tetap dengan maksud agar meningkatkan keuntungan potensial pemegang saham. Penggunaan hutang dalam kegiatan pendanaan perusahaan tidak hanya memberikan dampak yang baik bagi perusahaan. Jika proporsi leverage tidak diperhatikan perusahaan, hal tersebut akan menyebabkan turunnya profitabilitas, karena penggunaan hutang menimbulkan beban bunga yang bersifat tetap (Arifin, Sarita, \& Madi, 2018). Debt to Equity Ratio (DER) adalah rasio yang digunakan untuk menilai utang dengan ekuitas. Rasio ini berguna untuk mengetahui jumlah dana yang disediakan oleh peminjam (kreditor) dengan pemilik perusahaan. Rasio ini berfungsi untuk mengetahui setiap rupiah modal sendiri yang digunakan untuk jaminan utang (Hakim, 2018). Semakin tinggi tingkat solvabilitas atau leverage suatu perusahaan maka mencerminkan bahwa tingkat utang perusahaan tersebut juga tinggi selain itu juga menunjukkan bahwa semakin besar tingkat resiko keuangan yang akan dialami oleh kreditor maupun investor (Hakim, 2018). Salah satu indikator financial leverage yang akan digunakan dalam penelitian ini adalah rasio utang terhadap modal (total debt to equity ratio). Menurut Hery (2016) rasio hutang terhadap modal merupakan rasio yang digunakan untuk mengukur besarnya proporsi utang terhadap modal.

\section{Price to Book Value}

Price to Book Value merupakan hubungan antara harga saham dan nilai buku per lembar saham. Rasio ini bisa juga dipakai sebagai pendekatan alternatif untuk menentukan nilai suatu saham karena secara teoritis nilai pasar suatu saham haruslah mencerminkan nilai bukunya. Makin tinggi rasio ini berarti pasar makin percaya akan prospek perusahaan tersebut. Sebagai suatu perusahaan yang memiliki manajemen yang baik, diharapkan PBV dari perusahaan tersebut, setidaknya adalah satu atau dengan kata lain di atas dari nilai bukunya. Jika PBV perusahaan di bawah satu, kita dapat menilai bahwa harga saham tersebut adalah di bawah nilai buku. Jika angka PBV di bawah satu, dapat dipastikan bahwa harga pasar saham tersebut lebih rendah dari pada nilai bukunya (M. Sari \& Jufrizen, 2019). 


\section{Kerangka Konseptual}

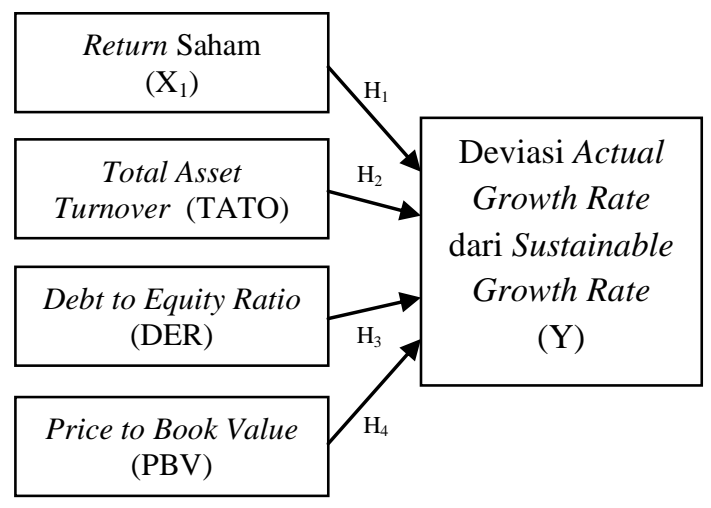

\section{Perumusan Hipotesis}

$\mathrm{H}_{1} \quad$ : Return Saham berpengaruh negatif terhadap Deviasi Actual Growth Rate dari Sustainable Growth Rate.

$\mathrm{H}_{2}$ : Total Asset Turnover (TATO) berpengaruh negatif terhadap Deviasi Actual Growth Rate dari Sustainable Growth Rate.

$\mathrm{H}_{3}$ : Debt to Equity Ratio (DER) berpengaruh positif terhadap Deviasi Actual Growth Rate dari Sustainable Growth Rate.

$\mathrm{H}_{4}$ : Price to Book Value (PBV) berpengaruh negatif terhadap Deviasi Actual Growth Rate dari Sustainable Growth Rate.

\section{METODE PENELITIAN \\ Pendekatan Penelitian}

Penelitian ini bersifat kuantitatif dan metode yang digunakan dalam penelitian ini adalah metode deskriptif dan verifikatif.

\section{Tempat dan Waktu Penelitian}

Penelitian ini dilakukan pada Bursa Efek Indonesia (BEI). Ditetapkannya Bursa Efek Indonesia sebagai tempat penelitian dengan mempertimbangkan bahwa Bursa Efek Indonesia merupakan salah satu pusat penjualan saham perusahaan yang go public di Indonesia. Waktu penelitian dimulai pada saat penulis mengajukan riset untuk penelitian ini yaitu dimulai dari bulan April sampai Agustus 2019.

\section{Definisi dan Pengukuran Variabel Variabel Dependen}

Variabel dependen yaitu variabel yang dipengaruhi oleh variabel lain. Dalam penelitian ini akan menggunakan variabel dependen Deviasi actual growth rate dari sustainable growth rate yang merupakan selisih antara persentase sustainable growth rate dengan actual growth rate. Variabel ini dapat diukur sebagai berikut :

$$
D A S=A G R-S G R
$$

Actual Growth Rate (AGR) merupakan persentase perubahan total penjualan perusahaan dalam tahun dasar dibanding total penjualan perusahaan tahun sebelumnya. Dirumuskan sebagai berikut :

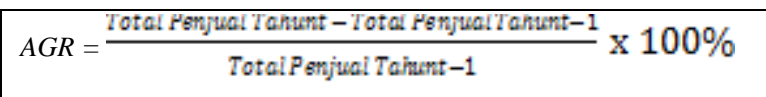

Sustainable Growth Rate (SGR) merupakan tingkat maksimum pertumbuhan penjualan perusahaan bias diperoleh tanpa pendanaan ekuitas eksternal. Dirumuskan sebagai berikut : \}

$S G R=\frac{R O E x R}{1-(\text { ROE } x R)} \times 100 \%$

\section{Variabel Independen Return Saham}

Return adalah hasil (keuntungan atau kerugian) yang diperoleh dari suatu investasi saham. Dalam penelitian ini perhitungan terhadap return hanya menggunakan return total, di mana return total membandingkan harga saham periode sekarang dengan harga saham sebelum periode sebelumnya. Dirumuskan sebagai berikut :

$$
\text { Return Saham }=\frac{\mathrm{Pt}-(\mathrm{Pt}-1)}{(\mathrm{Pt}-1)}
$$

\section{Asset Turnover}

Asset Turnover menggunakan proksi Total assets turnover (TATO), TATO dapat dihitung dengan membandingkan antara penjualan bersih dengan total aset yang dimiliki perusahaan. Dirumuskan sebagai berikut : 


$$
\text { TATO }=\frac{\text { Penjualan }}{\text { Total aset }} \times 100 \%
$$

\section{Leverage}

Tingkat hutang dalam penelitian ini menggunakan proksi dari tingkat leverage, merupakan perbandingan total debt dengan total ekuitas (hakim, 2017) Leverage menggunakan proksi Debt to Equity Ratio (DER), rasio ini dihitung sebagai hasil bagi antara utang dengan modal. Secara matematis dapat dirumuskan sebagai berikut :

$$
D E R=\frac{\text { Total liabilitas }}{\text { Total eluritas }}
$$

\section{Price to Book Value}

Price to Book Value (PBV) adalah perbandingan antara harga saham di pasar dengan nilai buku perusahaan tersebut. Dapat diirumuskan sebagai berikut :

$P B V=\frac{\text { Harga } \text { saham } / \text { lembar }}{\text { Nilaibuku ekuitas/lembar }}$

\section{Metode Pengambilan Sampel}

Pada penelitian ini metode pengambilan sampel yang digunakan adalah metode purposive sampling, yaitu teknik penentuan sampel dengan pertimbangan atau kriteria-kriteria tertentu (Sujarweni, 2018).

\section{Metode Pegumpulan Data}

Metode pengumpulan data yang digunakan dalam penelitian ini adalah metode dokumentasi yang digunakan untuk mendapatkan laporan keuangan perusahaan seperti neraca dan laporan laba rugi selama periode penelitian yang ditetapkan.

\section{Metode Analisis Data Analisis Statistik Deskriptif}

Analisa statistik deskriptif memberikan gambaran atau deskripsi tentang suatu data yang diihat melalui nilai rata-rata (mean), standar deviasi, varian, maksimum, minimum, sum, range, kurtosis, dan skewness. (Pandoyo \& Sofyan, 2018).
Estimasi Regresi Data Panel

Menurut Pandoyo \& Sofyan (2018), ditinjau dari estimasi parameternya, model analisis regresi data panel dikelompokkan menjadi tiga pendekatan yaitu :

\section{Common Effect Model}

Analisis model common effect merupakan teknik yang paling sederhana mengansumsikan bahwa data gabungan yang ada menunjukkan data yang sesungguhnya. Dalam pendekatan estimasi ini, tidak diperlihatkan dimensi individu maupun waktu.

\section{Fixed Effect Model}

Model efek tetap atau fixed effect adalah bahwa satu objek memiliki konstanta yang tetap besarnya untuk berbagai periode waktu. Demikian juga dengan koefisien regresinya, tetap besarnya dari waktu ke waktu (time invariant).

\section{Random Effect Model}

Random Effect digunakan untuk mengatasi kelemahan metode efek tetap yang menggunakan variabel semu, sehingga model mengalami ketidakpastian. Tanpa menggunakan variabel semu, model efek random menggunakan residual, yang diduga memiliki hubungan antar waktu dan antar objek.

\section{Pemilihan Teknik Estimasi Regresi Data Panel}

Untuk menentukan model data yang tepat untuk digunakan dalam analisis regresi data panel, maka kita dapat melakukan pengujian, berikut :

\section{Uji Chow}

Uji Chow dilakukan untuk menentukan menentukan pendekatan yang lebih baik antara common effect dan fixed effect. Hipotesis dalam uji Chow adalah: $H_{0}=$ Model mengikuti Common Effect $H_{a}=$ Model mengikuti Fixed Effect 


\section{Uji Hausman}

Uji Hausman dilakukan untuk memilih model mana yang lebih baik, apakah menggunakan model fixed effect atau model random effect. Hal ini dilakukan setelah melakukan pengujian sebelumnya. Hipotesis dalam pengujian hausman test ada sebagai berikut:

$H_{0}=$ Model mengikuti Random Effect

$H_{a}=$ Model mengikuti Fixed Effect

\section{Uji Langrange Multiplier (LM)}

Uji Langrange Multiplier dilakukan untuk memilih model mana yang lebih baik, apakah menggunakan model random effect atau model common effect. Hal ini dilakukan setelah melakukan pengujian sebelumnya. Hipotesis dalam pengujian Langrange Multiplier ada sebagai berikut: $H_{0}=$ Model mengikuti Common Effect $H_{a}=$ Model mengikuti Random Effect

\section{Pegujian Hipotesis}

Uji Hipotesis secara bersama-sama (Uji F)

Uji F merupakan pengujian hubungan regresi secara simultan yang bertujuan untuk mengetahui apakah seluruh variabel independen bersama-sama mempunyai pengaruh yang signifikan terhadap variabel dependen. Adapun kriteria pengambilan keputusan sebagai berikut:

- Jika F-hitung < F-tabel dan nilai Signifikansi $>0.05$, maka diterima

- Jika F-hitung > F-tabel dan nilai Signifikansi $<0.05$, maka ditolak

\section{Koefisien Determinasi}

Koefisien determinasi $\left(\mathrm{R}^{2}\right)$ pada dasarnya mengukur seberapa jauh kemampuan model dalam menerangkan variasi variabel dependen. yang diperlukan untuk memprediksikan variabel-variabel dependen. Tetapi penggunaan koefisien determinasi tersebut memiliki suatu kelemahan, yaitu terdapatnya suatu bias terhadap jumlah variabel independen yang dimasukkan kedalam model. Agar terhindar dari bias tersebut, maka digunakan nilai adjusted $\mathrm{R}^{2}$, dimana nilai adjusted $\mathrm{R}^{2}$ mampu naik atau turun apabila terjadi penambahan satu variabel independen (Ghozali, 2013).

\section{Uji Hipotesis Secara Parsial (Uji t)}

Uji $t$ digunakan untuk menguji hipotesis secara parsial guna menunjukkan pengaruh tiap variabel independen secara individu terhadap variabel dependen. Cara pengujian parsial terhadap variabel independen yang digunakan dalam penelitian ini adalah sebagai berikut:

- Jika t-hitung < t-tabel dan nilai Signifikansi $>0.05$, maka diterima

- Jika t-hitung > t-tabel dan nilai Signifikansi $<0.05$, maka ditolak

\section{Analisis Regresi Data Panel}

Analisis Regresi Data Panel digunakan untuk menguji apakah Return Saham, Total Assets Turn Over (TATO), Debt to Equity Ratio (DER) dan Price to Book Value berpengaruh terhadap Deviasi Actual Growth Rate dari Sustainable Growth Rate (DAS). Penelitian ini menggunakan software Microsoft Excel 2007 dan Eviews 9 untuk pengolahan data penelitian.

Secara matematis persamaan regresi dalam model penelitian yang digunakan adalah sebagai berikut:

$\mathrm{DAS}_{i t}=\alpha+\beta_{1} \mathrm{RS}_{\mathrm{it}}+\beta_{2}$ TATO $_{\mathrm{it}}+\beta_{3} \mathrm{DER}_{\mathrm{it}}+\beta_{4} \mathrm{PBV}_{\mathrm{it}}+\varepsilon_{\mathrm{it}}$

\section{Hasil dan Pembahasan Analisis Statistik Deskriptif}

Tabel 1

Statistik Deskriptif

\begin{tabular}{|l|c|c|c|c|c|}
\hline & DAS & RS & TATO & DER & PBV \\
\hline Mean & -0.032706 & -0.023926 & 1.052044 & 0.684426 & 1.605662 \\
\hline Median & -0.029500 & -0.043500 & 0.914000 & 0.455000 & 1.112000 \\
\hline Maximum & 0.199000 & 0.752000 & 2.392000 & 2.655000 & 5.702000 \\
\hline Minimum & -0.466000 & -0.619000 & 0.240000 & 0.076000 & 0.046000 \\
\hline Std. Dev. & 0.096454 & 0.270993 & 0.528644 & 0.595889 & 1.444848 \\
\hline Observations & 68 & 68 & 68 & 68 & 68 \\
\hline
\end{tabular}

Sumber : Data diolah

Berdasarkan hasil analisis pada tabel di atas, ditunjukkan bahwa untuk variabel RS memiliki nilai rata-rata sebesar 0.023926 dengan standar deviasi sebesar 0.270993. Variabel TATO memiliki nilai rata-rata sebesar 1.052044 dengan standar deviasi sebesar 0.528644. Variabel DER 
memiliki nilai rata-rata sebesar 0.684426 dengan standar deviasi sebesar 0.595889 . Variabel PBV memiliki nilai rata-rata sebesar 1.605662 dengan standar deviasi sebesar 1.444848. Dari keempat variabel independen tersebut, hanya variabel RS yang memiliki nila rata-rata lebih kecil daripada standar deviasi sehingga RS memiliki tingkat risiko mengalami fluktuasi yang tinggi. Adapun variabel independennya (DAS) memiliki nilai ratarata sebesar -0.032706 dengan standar deviasi sebesar 0.096454 .

\section{Pemilihan Model Estimasi Model Uji Chow (Common Effect vs Fixed Effect)}

Redundant Fixed Effects Tests

Equation: EQ01

Test cross-section fixed effects

\begin{tabular}{|c|c|c|c|}
\hline Effects Test & Statistic & d.f. & Prob. \\
\hline Cross-section F & 4.640307 & $(16,47)$ & 0.0000 \\
\hline Cross-section Chi-square & 64.441218 & 16 & 0.0000 \\
\hline
\end{tabular}

Sumber : Data diolah dengan Eviews 9, 2019

Dengan menggunakan dasar keputusan seperti diatas, diketahui berdasarkan table distribusi $\mathrm{F}$ pada $\mathrm{df}=$ $(16,47)$ dengan $a=5 \%$ diperoleh nilai $\mathrm{f}_{\text {tabel sebesar 1.864. Maka dapat }}$ disimpulkan $F_{\text {hitung }}(4.640307)>F_{\text {tabel }}$ (1.864), yang artinya menolak $\mathrm{H}_{0}$. Maka model regresi linear berganda data panel dalam Uji Chow yang terbaik adalah menggunakan model regresi data panel dengan metode Fixed Effect.

\section{Uji Hausman (Fixed Effect vs Random Effect)}

\begin{tabular}{|c|c|c|c|}
\hline Test Summary & Chi-Sq. Statistic & Chi-Sq. d.f. & Prob. \\
\hline Cross-section random & 45.534539 & 4 & 0.0000 \\
\hline
\end{tabular}

Sumber : Data diolah dengan Eviews 9, 2019

Dengan menggunakan dasar keputusan seperti diatas, diketahui berdasarkan tabel distribusi Chi-square pada $\mathrm{df}=(4)$ dengan $\alpha=5 \%$ diperoleh nilai $t_{\text {abel }}$ sebesar 9.488. Maka dapat

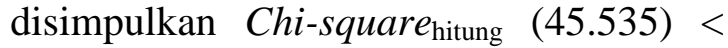
Chi-square $_{\text {tabel }}$ (9.488), yang artinya menolak $\mathrm{H}_{0}$. Maka model regresi linear berganda dalam Uji Hausman data panel yang terbaik adalah menggunakan model regresi data panel dengan metode Fixed Effect.

\section{Uji Langrage Multiplier (Common Effect vs Random Effect)}

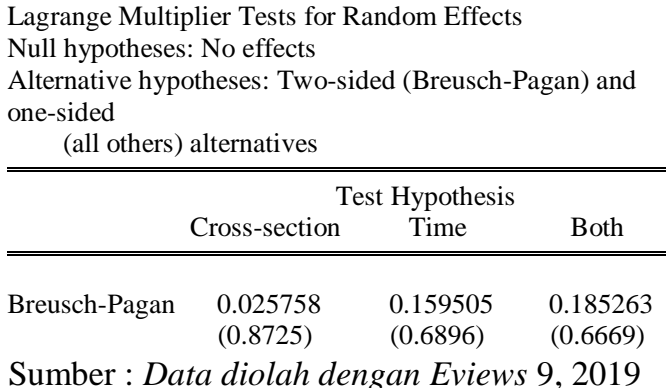

Berdasarkan hasil perhitungan diatas Cross-section Breusch-pagan (0.8725) > $\alpha$ $(0,05)$. Maka dapat disimpulkan bahwa model regresi data panel dalam Uji Langrage Multiplier yang lebih layak digunakan adalah Common Effect.

\section{Kesimpulan Model}

Berdasarkan pengujian terhadap ketiga model regresi data panel, dapat disimpulkan bahwa model fixed effect dalam regresi data panel digunakan lebih lanjut dalam mengestimasi pengaruh Return Saham, Total Assets Turn Over (TATO), Debt to Equity Ratio (DER) dan Price to Book Value berpengaruh terhadap Deviasi Actual Growth Rate dari Sustainable Growth Rate (DAS) pada perusahaan manufaktur yang terdaftar di Bursa Efek Indonesia pada tahun 20152018.

\section{Uji Asumsi Klasik Uji Multikolinearitas}


Tabel 2

Uji Multikolinearitas

\begin{tabular}{|l|c|c|c|c|c|}
\hline & DAS & RS & TATO & DER & PBV \\
\hline DAS & 1.000000 & 0.218015 & -0.178540 & -0.154810 & -0.067079 \\
\hline RS & 0.218015 & 1.000000 & 0.118412 & 0.188581 & 0.114215 \\
\hline TATO & -0.178540 & 0.118412 & 1.000000 & 0.250051 & -0.230199 \\
\hline DER & -0.154810 & 0.188581 & 0.250051 & 1.000000 & -0.422109 \\
\hline PBV & -0.067079 & 0.114215 & -0.230199 & -0.422109 & 1.000000 \\
\hline
\end{tabular}

Sumber : Data diolah dengan Eviews 9, 2019

Dengan menggunakan dasar keputusan seperti diatas, dapat disimpulkan bahwa hasil diatas tidak terdapat variabel independen yang memiliki nilai lebih dari 0.8 , sehingga dapat disimpulkan tidak terjadi multikolinieritas dalam model regresi.

\section{Uji Heterokedastisitas}

Tabel 3

Uji Heterokedastisitas

\begin{tabular}{lccc}
\hline \hline \multicolumn{1}{c}{ Test } & Statistic & d.f & Prob. \\
\hline \hline & & & \\
Breusch-Pagan LM & 162.5799 & 136 & 0.0597 \\
Pesaran scaled LM & 1.611646 & & 0.1070 \\
Bias-corrected scaled LM & -1.221687 & & 0.2218 \\
Pesaran CD & 1.779577 & & 0.0751
\end{tabular}

Sumber : Data diolah dengan Eviews 9, 2019

Dengan menggunakan dasar keputusan seperti diatas, diketahui Probabilitas Breusch-Pagan LM (0.0597) $>\alpha(0,05)$, yang artinya $\mathrm{H}_{0}$ diterima. Maka dengan demikian dapat disimpulkan bahwa model regresi data panel tidak terjadi Heteroskedastisitas.

\section{Uji Hipotesis}

\section{Uji F}

\begin{tabular}{|c|c|}
\hline F-statistic & 4.950799 \\
\hline Prob(F-statistic) & 0.000003 \\
\hline
\end{tabular}

Dengan menggunakan dasar keputusan seperti diatas, diketahui Nilai statistik $\mathrm{F}$ dan nilai probabilitas statistik $\mathrm{F}$ pada penelitian ini adalah 4.950799 dengan probabilitas 0.000003 . Nilai statistik $F(4.950799)>F_{\text {tabel }}(2.51767)$ dan nilai probabilitas statistif $\mathrm{F}$ $(0.000003)<\alpha=0.05$ (5\%), maka dapat disimpulkan bahwa $\mathrm{H}_{0}$ ditolak. Dengan demikian, variabel bebas dalam penelitian ini yaitu return saham, assets turnover, leverage, dan price to book value mampu menjelaskan adanya hubungan secara signifikan terhadap variabel terikat yaitu Deviasi Actual Growth Rate dari Sustainable Growth Rate yang artinya penelitian ini layak untuk dilanjutkan.

\section{Koefisien Determinasi}

$\begin{array}{ll}\text { R-squared } & 0.678117 \\ \text { Adjusted R-squared } & 0.541146\end{array}$

$\overline{\text { Sumber }^{\prime}}=\overline{\overline{\text { Data diolah dengan Eviews 9, } 2019}}=$

Dari hasil perhitungan tersebut diperoleh besarnya pengaruh variabel independen terhadap variabel dependen yang dapat diterangkan oleh model dalam persamaan ini adalah sebesar 0.541146 atau sebesar $54.11 \%$. Hal ini menunjukan bahwa return saham, assets turnover, leverage, dan price to book value mampu menjelaskan variasi naik atau turunnya deviasi actual growth rate dari sustainable growth rate sebesar $54.11 \%$ sedangkan sisanya sebesar $45.89 \%$ dijelaskan oleh faktor-faktor lain selain return saham, assets turnover, leverage, dan price to book value yang tidak dimasukan dalam model regresi ini.

\section{Uji t}

\begin{tabular}{ccccc}
\hline \hline Variable & Coefficient & Std. Error & t-statistic & Prob. \\
\hline \hline C & -0.500759 & 0.155152 & -3.227532 & 0.0023 \\
RS & 0.125364 & 0.036125 & 3.470274 & 0.0011 \\
TATO & 0.391660 & 0.149934 & 2.612217 & 0.0120 \\
DER & 0.307743 & 0.059556 & 5.167303 & 0.0000 \\
PBV & -0.094427 & 0.022095 & -4.273686 & 0.0001 \\
\hline \hline
\end{tabular}

Sumber : Data diolah dengan Eviews 9, 2019

Dari tabel diatas hasil analisis regresi data panel didapatkan sebagai berikut: 
DAS $=-0.50076+0.12536 \mathrm{RS}+0.39166 \mathrm{TATO}+$ 0.30774DER - 0.09443PBV $+\varepsilon$

Berdasarkan hasil perhitungan menggunakan Eviews 9 dapat dilihat bahwa dari keempat variabel diatas yakni Return Saham (RS), Asset Turnover (TATO), Leverage (DER) dan Price to Book Value (PBV) berpengaruh terhadap deviasi actual growth rate dari sustainable growth rate.

\section{PEMBAHASAN}

Pengaruh Return Saham terhadap Deviasi Actual Growth Rate dari Sustainable Growth Rate

Variabel Return Saham (RS) mempunyai nilai signifikansi sebesar $0.001<$ dari taraf signifikansi 0,05 dengan diperolehnya koefisien untuk variabel return saham sebesar 0.12536 . Berdasarkan hasil tersebut maka dapat dikatakan bahwa return saham berpengaruh positif terhadap deviasi actual growth rate dari sustainable growth rate pada perusahaan manufaktur yang terdaftar di BEI.

Namun hasil ini menunjukkan bahwa harga saham perusahaan manufaktur periode 2015-2018 pada penelitian ini umumnya mengalami penurunan dari harga saham tahun sebelumnya yang berdampak menurunnya nilai sustainable growth rate. Sehingga penurunan sustainable growth rate tersebut dapat meningkatkan nilai deviasi actual growth rate dari sustainable growth rate.

Hasil ini berbeda dengan penelitian yang dilakukan Saputro \& Purwanto (2013) yang menyatakan bahwa Return Saham berpengaruh negatif dan tidak siginifikan terhadap Deviasi Actual Growth Ratedari Sustainable Growth Rate karena kenaikan return saham akan berdampak pada laba perusahaan yang kemudian dapat meningkatkan Sustainable Growth Rate dan menurunkan Deviasi Actual Growth Ratedari Sustainable Growth Rate.
Pengaruh Assets Turnover terhadap Deviasi Actual Growth Rate dari Sustainable Growth Rate

Variabel Asset Turnover (TATO) mempunyai nilai signifikansi sebesar 0.012 < dari taraf signifikansi 0,05 dengan diperolehnya koefisien regresi untuk variabel independen Total Assets Turnover (TATO) sebesar 0.39166. Berdasarkan hasil tersebut maka dapat dikatakan bahwa assets turnover berpengaruh positif terhadap deviasi actual growth rate dari sustainable growth rate.

Hasil ini menunjukkan bahwa perusahaan manufaktur periode 20152018 pada penelitian ini hanya berlomba meningkatkan prospek pertumbuhan penjualan, namun tidak memperhatikan prospek pertumbuhan laba. Peningkatan penjualan yang tidak diimbangi dengan meningkatnya laba bersih setelah pajak, maka akan menurunkan nilai sustainable growth rate sehingga nilai deviasi actual growth rate dari sustainable growth rate akan meningkat.

Hasil ini berbeda dengan penelitian yang dilakukan Nasim \& Rizki Irnama (2017) yang menyatakan asset turnover memiliki pengaruh positif terhadap sustainable growth rate karena semakin tinggi assets turnover yang dimiliki perusahaan maka sustainable growth rate perusahaan akan meningkat, sehingga deviasi actual growth rate dari sustainable growth rate akan menurun.

Pengaruh Leverage terhadap Deviasi Actual Growth Rate dari Sustainable Growth Rate

Variabel Leverage (DER) mempunyai nilai signifikansi sebesar $0.000<$ dari taraf signifikansi 0,05 dengan diperolehnya koefisien regresi untuk variabel independen Debt to Equity Ratio (DER) sebesar 0.30774. Berdasarkan hasil tersebut maka dapat dikatakan bahwa leverage berpengaruh posotif terhadap deviasi actual growth rate dari sustainable growth rate. Dengan demikian dapat disimpulkan bahwa meningkatnya DER akan menimbulkan bunga yang menjadi beban suatu 
perusahaan yang akan berdampak pada menurunnya suntikan dana dari pihak eksternal sehingga sustainable growth rate akan turun dan deviasi actual growth rate dari sustainable growth rate akan meningkat.

Hasil ini sejalan dengan penelitian yang dilakukan Nasim U. L. Sari (2014) yang menyatakan bahwa terdapat hubungan positif dari DER terhadap deviation actual growth rate dari sustainable growth ratekarena semakin tinggi Debt to Equity Ratio suatu perusahaanakan meningkatkan nilai deviation actual growth rate dari sustainable growth rate.

\section{Pengaruh Price to Book Value terhadap Deviasi Actual Growth Rate dari Sustainable Growth Rate}

Variabel Price to Book Value (PBV) mempunyai nilai signifikansi sebesar 0.000 < dari taraf signifikansi 0,05 dengan diperolehnya koefisien regresi untuk variabel independen Price to Book Value (PBV) sebesar -0.09446. Dapat disimpulkan bahwa peningkatan nilai pasar perusahaan akan meningkatkan nilai penjualan, hal ini mendorong perusahaan memperbesar dividen yang dapat memperkecil retention rate. sehingga para investor akan tertarik dan merasa aman untuk berinvestasi. Peningkatkan nilai Price to Book Value akan miningkatkan sustainable growth rate sehingga menurunkan deviasi actual growth rate dari sustainable growth rate.

Hasil ini sejalan dengan penelitian yang dilakukan U. L. Sari (2014) yang menyatakan bahwa Price to Book Value (PBV) berpengaruh negatif terhadap deviation actual growth rate dari sustainable growth rate karena setiap kenaikan atau penurunan nilai PBV akan berdampak pada peningkatan atau penurunan nilai deviationactual growth rate dari sustainable growth rate.

\section{KESIMPULAN DAN SARAN Kesimpulan}

Berdasarkan hasil pengujian yang telah dilakukan, dapat disimpulkan beberapa hal, yaitu: a. Variabel Return Saham (RS) berpengaruh positif terhadap deviasi actual growth rate dari sustainable growth rate pada perusahaan manufaktur yang terdaftar di Bursa Efek Indonesia tahun 2015 sampai dengan 2018. Hal ini di buktikan dengan nilai koefisiennya sebesar 0.125364 dan $p$-value uji t lebih kecil dari alfa $5 \%(0.05)$ yaitu 0,001 .

b. Variabel Assets Turnover yang diproksikan oleh Total Assets Turnover (TATO) berpengaruh positif terhadap deviasi actual growth rate dari sustainable growth rate pada perusahaan manufaktur yang terdaftar di Bursa Efek Indonesia tahun 2015 sampai dengan 2018. Hal ini di buktikan dengan nilai koefisiennya sebesar 0.391660 dan p-value uji $\mathrm{t}$ lebih kecil dari alfa $5 \%(0.05)$ yaitu 0,012 .

c. Variabel Leverage yang diproksikan oleh Debt to Equity Ratio (DER) berpengaruh positif terhadap deviasi actual growth rate dari sustainable growth rate pada perusahaan manufaktur yang terdaftar di Bursa Efek Indonesia tahun 2015 sampai dengan 2018. Hal ini di buktikan dengan nilai koefisiennya sebesar 0.307743 dan $p$-value uji t lebih kecil dari alfa 5\% (0.05) yaitu 0,000.

d. Variabel Price to Book Value (PBV) berpengaruh negatif terhadap deviasi actual growth rate dari sustainable growth rate pada perusahaan manufaktur yang terdaftar di Bursa Efek Indonesia tahun 2015 sampai dengan 2018. Hal ini di buktikan dengan nilai koefisiennya sebesar 0.094427 dan $p$-value uji t lebih kecil dari alfa $5 \%(0.05)$ yaitu 0,000 .

e. Pengujian dengan uji kelayakan model (Uji F) menunjukkan bahwa return saham, assets turnover, leverage, dan price to book value mampu menjelaskan adanya hubungan secara signifikan terhadap Deviasi Actual Growth Rate dari Sustainable Growth Rate yang artinya penelitian ini layak untuk dilanjutkan. Nilai koefisien determinasi sebesar 0.541146 yang 
berarti bahwa return saham, assets turnover, leverage, dan price to book value mempunyai pengaruh terhadap variabel Deviasi Actual Growth Rate dari Sustainable Growth Rate sebesar $54,11 \%$. Sedangkan sisanya sebesar $45,89 \%$ dijelaskan oleh faktor-faktor lain diluar variabel bebas dalam penelitian ini.

\section{DAFTAR PUSTAKA}

Arifin, Dedy Samsul, Sarita, B., Dan Madi, Riski Amalia. 2018. Pengaruh Likuiditas, Leverage, Ukuran Perusahaan Dan Pertumbuhan Penjualan Terhadap Profitabilitas. Kendari: Universitas Halu Oleo.

Ghozali, Imam. 2013. Aplikasi Analisis Multivariate Dengan Program Spss. Edisi Ketujuh. Semarang: Badan Penerbit Universitas Diponegoro.

Gunawan, Barbara, Dan Dian Puteri Leonnita. 2015. Pengaruh Kinerja Keuangan Terhadap Deviation Actual Growth Rate Dari Sustainable Growth Rate. Jurnal Riset Akuntansi Dan Bisnis Vol. 15 (2). Yogyakarta: Universitas Muhammadiyah Yogyakarta.

Hakim, M. Z. (2018). Going Concern Audit Determination In Indonesian Agricultural Sector. Jabi (Jurnal Akuntansi Berkelanjutan Indonesia), 1(2), 226-235.

Hakim, M. Z. (2017). Determinan Konservatisme Akuntansi Pada Industri Dasar Dan Kimia Periode 2012-2014. Competitive, 1(1), 111135.

Hakim, M. Z., \& Abbas, D. S. (2019). Pengaruh Price Earning Ratio, Earning Per Share, Return On Equity, Debt To Equity Ratio Dan Net Profit Margin Terhadap Return Saham (Pada Sektor Property And Real Estate Yang Terdaftar Di
Bursa Efek Indonesia Periode 20132017). Competitive, 3(1), 1-20.

Hermuningsih, Sri, Rahmawati, A. D., Dan Mujino. 2018. Faktor-Faktor Yang Mempengaruhi Return Saham. Jurnal Ekonomi Dan Bisnis. Malang: Universitas Islam Sultan Agung.

Hery. 2016. Financial Ratio For Business. Jakarta: Pt. Grasindo.3

Nasim, Arim, Dan Fetti Rizki Irnama. 2015. Pengaruh Profit Margin, Assets Turnover Dan Leverage Terhadap Sustainable Growth Rate Pada Perusahaan Sektor Jasa Yang Terdaftar Di Bursa Efek Indonesia Periode 2010-2012. Jurnal EAkuntansi, Vol. 3 (1). Bandung: Universitas Pendidikan Indonesia.

Pandoyo, Dan Sofyan, M. 2018. Metodologi Penelitian Keuangan Dan Bisnis. Bogor: In Media.

Parmanto, S. W., Dan Murtini, H. 2014. Determinan Deviasi Antara Actual Dan Sustainable Growth Rate Manufaktur Di Indonesia. Accounting Analysis Journal Vol. 3(3). Semarang: Universitas Negeri Semarang.

Putra, A. Y. 2015. Pengaruh Profitabilitas, Nilai Pasar, Likuiditas Dan Financial Leverage Terhadap Deviasi Actual Growth Rate Dari Sustainable Growth Rate. Skripsi. Jakarta: Universitas Negeri Jakarta.

Saputro, Adimas Wahyu, Dan Agus Purwanto. 2013. Pengaruh Hubungan Kinerja, Likuiditas Dan Return Saham Terhadap Deviasi Actual Growth Rate Dari Sustainable Growth Rate Pada Perusahaan Manufaktur Di Bursa Efek Indonesia. Jurnal E-Akuntansi, Vol. 2 (3). Semarang: Fakultas Ekonomika Dan Bisnis Universitas Diponegoro.

Sari, M., Dan Jufrizen. 2019. Pengaruh Price Earning Ratio Dan Return On Asset Terhadap Price To Book Value. Kumpulan Riset Akuntansi Vol. 10(2). Medan: Universitas Muhammadiyah Sumatera Utara. 
Sari, U. Linda. 2014. Pengaruh Kinerja Keuangan Dan Financial Distress Terhadap Deviation Actual Growth Rate Dari Sustainable Growth Rate. Skripsi. Yogyakarta: Universitas Muhammadiyah Yogyakarta.

Sujarweni, V. W. 2018. Metodologi Penelitian Bisnis Dan Ekonomi

\section{Pendekatan}

Kuantitatif.

Yogyakarta: Pustaka Baru Press. Wardiyah, M. L. 2017. Analisis Laporan Keuangan. Bandung: Cv Pustaka Setia. Http://Finance.Yahoo.Com Tanggal Di Akses 17 Juni 2019 Http://Idx.Com Tanggal Di Akses 17 Juni 2019 
